\title{
Analysis of the presence of nutrient claims on labels of ultra-processed foods directed at children and of the perception of kids on such claims
}

\author{
Análise da presença de alegações nutricionais \\ em embalagens de alimentos ultraprocessados \\ direcionados a crianças e da percepção \\ infantil com relação a estas alegações
}

Natália Durigon ZUCCHI ${ }^{1}$

Giovanna Medeiros Rataichesck FIATES²

A B S T R A C T

\section{Objective}

To characterize the presence of nutrient claims on the front-of-pack labels of ultra-processed foods directed at children and gain insight on children' views about the presence of marketing strategies and nutrient claims on labels of ultra-processed foods.

\section{Methods}

Analysis of images (front panel, nutrition facts table, and ingredients list) of labels from 535 packaged foods with marketing strategies directed at children obtained in an audit-type survey conducted at a Brazilian large supermarket store. Food products with ultra-processed characteristics were identified, and the nutrient claims were quantified and described. Focus groups were conducted with children aged 8-10 years.

\section{Results}

A total of $472(88.0 \%)$ of the 535 packaged foods directed at children were classified as ultra-processed. Of these, $220(46.6 \%)$ had one or more nutrient claims on their front-of-pack label $(n=321)$, most $(n=236,73.5 \%)$

\footnotetext{
1 Universidade Federal de Santa Catarina, Programa de Pós-Graduação em Nutrição. Florianópolis, SC, Brasil.

${ }^{2}$ Universidade Federal de Santa Catarina, Departamento de Nutrição, Programa de Pós-Graduação em Nutrição. Campus Universitário João David Ferreira Lima, Trindade, 88040-900, Florianópolis, SC, Brasil. Correspondência para/Correspondence to: GMR FIATES. E-mail: <giovanna.fiates@ufsc.br>.

Article based on the master's thesis of ND ZUCCHI entitled: "Alimentos ultraprocessados direcionados a crianças: disponibilidade, informação nutricional complementar e opinião de consumidores infantis”. Universidade Federal de Santa Catarina; 2015.

Support: Agência Nacional de Vigilância Sanitária (Process no 440040/2014-0) and Coordenação de Aperfeiçoamento de Pessoal de Nivel Superior.
} 
claiming the presence/increased quantities of vitamins and minerals. The most common 'free/reduced' content claim regarded trans fat content $(n=48)$. The focus groups allowed the identification of a noticeable influence of nutrition claims on children, who considered the emphasis important but were confused by the meaning and focus of such claims.

\section{Conclusion}

Highlighted nutrient claims on the packages of ultra-processed foods were common and seemed to influence the children's perception of the products' quality as a whole. The results indicate the need of thoroughly reviewing the legislation on nutrient claims on the packages of ultra-processed foods.

Keywords: Child. Focus groups. Marketing. Nutritional labeling.

\section{RE S U M O}

\section{Objetivo}

Caracterizar a presença de alegações nutricionais no painel frontal de embalagens de alimentos ultraprocessados direcionados a crianças e conhecer a percepção infantil no que diz respeito à presença de estratégias de marketing e alegações nutricionais nos rótulos dos mesmos.

\section{Métodos}

Foi realizada a análise de imagens fotográficas (painel frontal, tabela nutricional e lista de ingredientes) de rótulos de 535 alimentos embalados com estratégias de marketing para o público infantil obtidas em levantamento censitário em supermercado brasileiro de grande porte. Também foi feita a identificação de produtos com características de ultraprocessados e a posterior quantificação e descrição das alegações nutricionais presentes. Foram conduzidos grupos focais com crianças de oito a 10 anos.

\section{Resultados}

Um total de 472 (88.0\%) dos 535 alimentos embalados direcionados a crianças foram classificados como ultraprocessados. Destes, $220(46,6 \%)$ apresentaram uma ou mais alegações nutricionais em seu painel frontal $(n=321)$, a maioria $(n=236,73,5 \%)$ relativa à presença ou quantidade aumentada de vitaminas e minerais. $A$ alegação de isenção/redução mais encontrada foi relativa ao conteúdo de gordura trans $(n=48)$. Nos grupos focais, foi possivel perceber a influência da presença de alegações nutricionais sobre as crianças, as quais consideraram importante o destaque nas embalagens, mas manifestaram confusão quanto ao teor e ao foco das mesmas.

\section{Conclusão}

O destaque de alegações nutricionais em embalagens de alimentos ultraprocessados direcionados a crianças foi comum nos produtos analisados e pareceu influenciar a percepção infantil sobre a qualidade do produto como um todo. Os resultados indicam a necessidade de revisão criteriosa da legislação referente à presença de alegações nutricionais em embalagens de alimentos ultraprocessados.

Palavras-chave: Criança. Grupos focais. Marketing. Rotulagem nutricional.

\section{INTRODUCTION}

Food processing techniques have undergone many advances over the centuries. Technological innovations increasingly seek to facilitate preparation and transportation, generating packaged, refrigerated, or frozen pre-prepared foods ${ }^{1}$. However, many foods introduced in the market taking advantage of these innovations are low in fiber and high in calories, sugar, sodium, and trans fats ${ }^{2}$, and are classified by the Guidelines for the Brazilian Population as Ultra-Processed Foods (UPF) ${ }^{3}$.

The use of nutritional marketing strategies and nutrient claims on UPF packages is common, even in UPF directed at children ${ }^{4,5}$. Marketing strategies aim to create positive associations with the food and package by employing mechanisms such as fun, functionality, and interactivity ${ }^{6}$. Nutrient claims are inscriptions that affirm, suggest, or imply that a food has particular nutritional properties related to its content of energy, 
proteins, fats, carbohydrates, dietary fibers, vitamins, and/or minerals ${ }^{7}$.

A study that investigated the quality of breakfast cereals in 32 countries found that most cereals had high sugar and sodium contents, and that the packages contained cartoon characters, gifts, collectibles, games, and nutrient claims ${ }^{8}$. Studies conducted in the United States of America found that children preferred and identified as healthier and/or tastier foods that contained nutrient claims or cartoon characters on their labels ${ }^{9,10}$. In Canada and Guatemala studies found that children strongly relied on the visual aspects of the packages to consider foods healthier ${ }^{11}$ and make their food choices ${ }^{12}$.

Highlighting positive characteristics in the form of nutrient claims on the front-of-pack label can generate the so-called halo effect, when consumers' assessment of a single positive characteristic of the food affects their judgment about the quality of the food as a whole ${ }^{13}$. For example, the addition of synthetic vitamins and minerals to sodas and energy-dense snacks is not going to make these items healthy, but consumers may be led to believe so ${ }^{14}$.

The most recent Pesquisa de Orçamentos Familiares (POF, Family Budget Survey) conducted by the Instituto Brasileiro de Geografia e Estatística (IBGE, Brazilian Institute of Geography and Statistics) shows a growing trend to replace staple and traditional foods of the Brazilian diet (rice, beans, vegetables) with ultra-processed foods ${ }^{15}$, whose excessive intake is associated with obesity and other chronic non-communicable diseases in children ${ }^{16}$.

The Brazilian regulatory system has been working to ensure a social environment that favors the promotion of a healthy diet. In 2006 the Agência Nacional de Vigilância Sanitária (ANVISA, National Sanitary Surveillance Agency) conducted a public consultation about regulating the supply, and advertising of low-nutrient foods ${ }^{17}$. A resolution based on the approved text would go into effect in December 2010'8, but the Associação Brasileira das Indústrias da Alimentação
(ABIA, Brazilian Association of Food Companies) managed to suspend the enforcement of this resolution on its members ${ }^{19}$.

In 2014 Resolution $n^{\circ} 163$ of 2014 of the Conselho Nacional dos Direitos da Criança e do Adolescente (CONANDA, National Council for the Rights of (Children and Adolescents) was passed. This resolution considers that directing advertising and marketing communication at children to persuade them to consume any product or service is abusive, and therefore, illegal ${ }^{20}$.

Also in 2014, Ordinance $n^{\circ}$ 949/2014/ ANVISA instituted the Working Group for Nutritional Labeling, and one of its objectives is to help identify problems and limitations of the current regulatory model and propose alternatives to solve them ${ }^{21}$.

Given the above, the present study aimed to characterize the availability of UPF in the retail market and identify marketing strategies and nutrient claims directed at children. Additionally, the study investigated the opinion of child consumers on UPF packages with marketing strategies and nutrient claims on their front-of-pack labels.

\section{METHODS}

This audit study conducted in a supermarket from one of the ten largest supermarket chains in Brazil identified 5620 packaged products of which 535 were classified as directed at children because they had marketing strategies targeting this age group on their front-of-pack labels ${ }^{22}$. The packages of all products were photographed for analysis.

Information on the front-of-pack label, nutritional facts label, and/or list of ingredients of 535 packaged foods directed at children were analyzed to determine how many would be classified as UPF according to the classification proposed by the Guidelines for the Brazilian Population ${ }^{3}$. Table 1 presents categories and examples of ultra-processed foods. 
Table 1. Categories and examples of Ultra-Processed Foods (UPF) used for classifying the packaged foods directed at children available at a large Brazilian supermarket $(n=535)$.

Ultra-processed foods

\begin{tabular}{ll}
\hline Ready-to-eat snacks, other & Sandwich cookies, ice creams, candies, chocolates (bar, cream, powder), and sweets in general; jello; \\
snacks, or desserts & sugared breakfast cereals; filled cakes; cake sprinkles; cake mixes; cereal bars; microwave popcorn; \\
& instant soups, noodles and condiments; sauces; packaged savoury snacks; carton juices; instant fruit \\
& juice mixes; sodas; yogurts and milk-based beverages with added sugar; other beverages with added \\
& sugar. \\
& Pasta-based dishes, pizzas, lasagnas, hamburger patties, chicken or fish nuggets, frozen French fries, \\
& hot dogs, cold cuts, and cured meats; hamburger buns, sliced bread, hot dog buns, sweet buns; and \\
Ready-to-heat foods & other baked goods containing hydrogenated vegetable fat, starch, whey, emulsifiers, and other \\
& additives.
\end{tabular}

Source: "Guia alimentar para a população brasileira"s.

Later on, the front-of-pack labels of foods classified as UPF were analyzed to identify the presence and type of nutrient claim present on the packages according to RDC $n^{\circ} 54 / 2012$. This Resolution states that claims are divided into declarations of properties related to the absolute content and to the comparative content of nutrients ${ }^{7}$.

Absolute content claims are those that describe the level and/or quantity of one or more nutrients and/or energy content of a food. The allowed terms are: low (little, low content of, light in); does not contain (free of, zero, 0, 0\%, without, -free); high content (rich in, high content); source (with, contains); very low and without added (zero addition of, without). Absolute content claims can be made for the contents of energy, sugars, total fats, saturated fats, trans fats, $\omega-3,-6$, and -9 fatty acids, cholesterol, sodium, proteins, dietary fiber, vitamins, and minerals ${ }^{7}$.

On the other hand, comparative content claims are those that compare the levels of the same nutrient(s) or energy of the food in question with a reference food. Comparative nutritional content claims may be made for contents of energy, sugars, total and saturated fats, cholesterol, sodium, protein, dietary fiber, vitamins, and minerals?.

During the third and last stage of the study, focus groups were conducted with child consumers to investigate how they perceived marketing strategies and nutritional claims on UPF labels. Packages of UPF listed by the literature as commonly consumed by children ${ }^{23}$, with different types of nutritional claims on the front-of-pack labels, and that could be consumed during main meals or snacks were selected for the children to examine and manipulate during the focus groups (Table 2).

The sides and back of the packages were covered to induce discussion only about the information contained in the front-of-pack label, and the packages were presented to all focus groups in the same order (mini hot dog buns/ chicken nuggets/packaged chips/chocolate milk).

A discussion guide was developed based on theoretical background about conducting focus groups with children ${ }^{24}$, discussed with researchers experienced in the methodology, and tested in a pilot:

- What do you think about this package, does anything draw your attention? [What? Why?]

- Does anything on the package make you want to eat this food? [What? Why?]

- Why do you think the package has this character/drawing/image?

- And the things that are written on the package, what do you think they mean? 
Table 2. Characteristics of ultra-processed food packages chosen to guide focus groups with child consumers. Florianópolis, Brazil, 2015.

\begin{tabular}{|c|c|c|c|}
\hline Food & Images & Nutritional claim & Other information* \\
\hline \multirow[t]{2}{*}{ Mini sub roll } & - Image of a boy & - Source of vitamins A and D & - whole \\
\hline & - Video game buttons & - $0 \%$ trans fat & - 'Play' \\
\hline \multirow[t]{3}{*}{ Chicken nugget } & - Comic book character & - Source of vitamins B1, B2, and B6 & \\
\hline & & - High in vitamin B12 & - \\
\hline & & - Source of iron and zinc & \\
\hline Packaged salty chips & $\begin{array}{l}\text { - Image of an animal character related to the } \\
\text { brand }\end{array}$ & $\begin{array}{l}-25 \% \text { less sodium and saturated fat } \\
\text { - } 0 \% \text { trans fat }\end{array}$ & Transgenic symbol (T) \\
\hline \multirow[t]{2}{*}{ Chocolate milk } & - Brand-related character performing a soccer & - Light: 50\% fewer calories & - Gift included (sticker) \\
\hline & 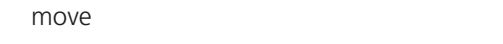 & & - Total energy content \\
\hline
\end{tabular}

Note: *Highlighted label contents that do not meet the definition of nutrient claims, such as written words, symbols, and energy content.

- And this thing written here [reading the nutrient claim aloud], why do you think it is here? For whom do you think this information matters? Would it make any difference if it were not here?

The study included boys and girls aged 8 to 10 years enrolled in the morning and afternoon classes of a private school in a Brazilian state capital. A private school was chosen because other studies conducted in the municipality had identified that children from private schools were more likely to consume ultra-processed foods ${ }^{25}$. The chosen age group was that of the analytical stage of consumer socialization, in which children are capable of making a weighted assessment about a theme, considering many attributes and analyzing the cost/benefit relationship ${ }^{26}$.

The students were only enrolled in the study if their parents or guardians signed an informed consent form. The project was approved by the Human Research Ethics Committee of the institution responsible for the study under number CAAE n 43858015.0.0000.0115.

The groups, held during the usual class time, consisted of four to six participants of same age and sex and lasted 40 minutes at most ${ }^{24}$. Each group was conducted by a trained moderator, who was aided by an observer. The children were asked to sit in a circle and make themselves comfortable, allowing good eye contact and equal distance between all participants. The packages were placed at the beginning of the focus group at the center of the circle, and the children were free to pick them up and examine them. Before the moderator started asking the scripted questions, the children were informed that the conversation was going to be recorded and that they could leave at any time at their discretion. The importance of expressing opinions and ideas without worrying about being right or wrong was also made clear.

The content recorded during the focus groups was transcribed verbatim to produce a single manuscript, to which the observer/ researcher's notes were added. The manuscript and recordings were read and listened to repeatedly to detect different speech intonations and take notes on the margins of the sheets. The text was later submitted to content analysis ${ }^{27}$. The data were initially treated by codifying the material by enumeration, cuts, and aggregation of words and/or sentences. Later came the categorization stage, where the codified elements were classified into themes and categories. Weak and generalist categories were regrouped until they originated strong or terminal categories ${ }^{27}$.

\section{RES U LT S}

Of the identified 535 packaged foods directed at children, 472 (88.0\%) were classified as ultra-processed foods. Of the 472 UPF, 220 
(46.6\%) presented one or more nutrient claims on the front-of-pack label $(n=321)$ regarding the presence/increase or reduction/absence of some component.

The highest number of nutrient claims was identified on the front-of-pack labels of UPF such as sandwich cookies, filled cakes, jello, gummy candies, carton juices, instant fruit drink mixes, sweetened yogurts, milk-based beverages, and packaged savoury snacks. Ultra-processed foods that rarely had claims on the front-of-pack label were cake sprinkles, sodas, candies, chocolate bars, pizzas, lasagnas, and hamburger patties.

Table 3 describes the nutrient claims of presence/increase and reduction/absence of component(s), and Table 4 shows the types of UPF with such claims.

Of the $236(73.5 \%)$ nutrient claims of presence/increase of component(s), the most common were 'with/source of/contains' vitamins $(n=92)$ and minerals $(n=75)$, present mainly on the packages of sandwich cookies, sweetened yogurts, instant fruit drink mixes, and jello. Eighty-five products (26.5\%) presented reduction/ absence claims, most of which regarded trans fats $(n=48)$. This type of claim on the label was made most frequently on filled cakes, instant fruit drink mixes, and sweetened yogurts.

\section{Focus groups with children}

Nine focus groups with 49 children (27 boys) were conducted. Asking them what drew their attention on the front-of-pack labels encouraged them to provide numerous answers, demonstrating their familiarity with the presented foods/packages.

Mini sub rolls and chocolate milk packages evoked the highest number of comments. The interviewees associated the drawings on the bun package (the image of a boy, a button, and the word play) with playing video games. The character with a soccer ball on the chocolate milk package was associated with playing soccer.
According to the children, the images showed that the food provided energy and/or strength when consumed. '... it gives us strength to play video game...' (male fourth-grader) '... he's playing soccer! It's like he's drinking a lot of energy...' (female fourth-grader)

Regarding the presence of images on food packages, all groups recognized the use of characters to make them more attractive and induce purchase. The participants pointed out emphatically that the main reason for the character to be on the label was to get the children's attention. 'All products have it... they always have a character' (male fourth-grader) 'Yes! There is a child-character there!! Why else would it be there?' (female fourth-grader) 'Everyone knows the product is for children!!!' (male fifthgrader)

The interviewees recognized the cartoon characters on the labels, but the character of a popular comic book evoked the smallest number of comments. In half the groups the children affirmed perceiving that food packages present not only characters, but also some type of visual mechanism, such as figures, animals, and food images placed there to draw attention. One of the packages provided a gift, which the children considered a strategy to draw even more attention to the food and make people buy it, but the sticker provided with the chocolate milk was considered not fun and boring. 'They do this to draw attention, to sell more, whenever possible they offer a sticker or a tattoo' (female fourth-grader)

Questions about the claims present on the labels evoked a smaller number of comments than questions about the images. In six of the nine groups, the children affirmed that the written information (referring to the claims) aim to get the parents' or guardians' attention, not theirs. 'For the parents, yes, our parents always want to see whether the product will do us good' (male fourth-grader) 'Of the parents! Because they will think it is healthy so they will buy it for the children' (female fifth-grader). 
Table 3. Description of nutrient claims on the front-of-pack labels of ultra-processed foods emphasizing presence/increase of component(s). Florianópolis, Brazil, 2015.

With/Source of/Contains

Rich in /High content

Added/More

\begin{tabular}{|c|c|c|}
\hline & Foods & $\mathrm{n}$ \\
\hline \multirow{11}{*}{$\begin{array}{c}\text { Vitamins } \\
(\mathrm{n}=92)\end{array}$} & Sandwich cookie & 15 \\
\hline & Sweetened yogurt & 11 \\
\hline & Instant fruit drink mix & 10 \\
\hline & Jello & 10 \\
\hline & Filled cake & 9 \\
\hline & Breakfast cereal with added sugar & 7 \\
\hline & Packaged savoury snack & 6 \\
\hline & Carton juice & 6 \\
\hline & Nuggets & 5 \\
\hline & Instant noodles & 3 \\
\hline & Chocolate spread & 4 \\
\hline \multirow{14}{*}{$\begin{array}{c}\text { Minerals } \\
(n=75)\end{array}$} & Milk-based beverage with added sugar & 3 \\
\hline & Sliced bread & 2 \\
\hline & Hamburger patties & 1 \\
\hline & Sandwich cookie & 15 \\
\hline & Sweetened yogurt & 10 \\
\hline & Instant fruit drink mixes & 10 \\
\hline & Breakfast cereal with added sugar & 8 \\
\hline & Filled cake & 7 \\
\hline & Carton juice & 6 \\
\hline & Nuggets & 5 \\
\hline & Packaged savoury snack & 5 \\
\hline & Chocolate spread & 4 \\
\hline & Milk-based beverage with added sugar & 3 \\
\hline & Sliced bread & 2 \\
\hline \multirow{4}{*}{$\begin{array}{l}\text { Fibers } \\
(\mathrm{n}=12)\end{array}$} & Packaged savoury snack & 4 \\
\hline & Sliced bread & 3 \\
\hline & Microwave popcorn & 3 \\
\hline & Cookies & 2 \\
\hline \multirow{4}{*}{$\begin{array}{c}\text { Proteins } \\
\quad(n=5)\end{array}$} & Cake & 2 \\
\hline & Microwave popcorn & 1 \\
\hline & Sliced bread & 1 \\
\hline & Packaged savoury snack & 1 \\
\hline \multirow{5}{*}{$\begin{array}{l}\text { Vitamins } \\
(n=21)\end{array}$} & Sweetened yogurt & 13 \\
\hline & Nuggets & 5 \\
\hline & Hot dog bun & 1 \\
\hline & Hamburger patties & 1 \\
\hline & Lasagna & 1 \\
\hline \multirow{5}{*}{$\begin{array}{c}\text { Minerals } \\
(n=12)\end{array}$} & Sweetened yogurt & 7 \\
\hline & Sandwich cookie & 2 \\
\hline & Breakfast cereal with added sugar & 1 \\
\hline & Lasagna & 1 \\
\hline & Processed cream cheese & 1 \\
\hline \multirow{4}{*}{$\begin{array}{l}\text { Vitamins } \\
(n=11)\end{array}$} & Sandwich cookie & 4 \\
\hline & Sweetened yogurt & 3 \\
\hline & Packaged savoury snack & 3 \\
\hline & Filled cake & 1 \\
\hline \multirow{3}{*}{$\begin{array}{c}\text { Minerals } \\
(n=8)\end{array}$} & Packaged savoury snack & 3 \\
\hline & Sandwich cookie & 3 \\
\hline & Filled cake & 2 \\
\hline
\end{tabular}


Table 4. Types of nutrient claims in foods emphasizing the reduction/absence of component(s). Florianópolis, Brazil, 2015.

\begin{tabular}{|c|c|c|c|}
\hline Reduction or Absence $(n=85)$ & & Foods & $\mathrm{n}$ \\
\hline & & Filled cake & 10 \\
\hline & & Gummy candy & 9 \\
\hline & & Packaged chips & 8 \\
\hline & & Sliced bread & 7 \\
\hline & & Nuggets & 3 \\
\hline \multirow[t]{7}{*}{ Does not contain/-free/Zero } & Trans fat $(n=48)$ & Sandwich cookie & 3 \\
\hline & & Instant noodles & 3 \\
\hline & & Microwave popcorn & 2 \\
\hline & & Cocoa powder & 2 \\
\hline & & Frozen French fries & 1 \\
\hline & Cholesterol $(n=02)$ & Sliced bread & 1 \\
\hline & & Microwave popcorn & 1 \\
\hline \multirow[t]{11}{*}{ Without/No added } & Sugar $(n=11)$ & Cake mixes & 2 \\
\hline & & Sweetened yogurt & 2 \\
\hline & & Carton juice & 2 \\
\hline & & Breakfast cereal with added sugar & 2 \\
\hline & & Soda & 1 \\
\hline & & Packaged savoury snack & 1 \\
\hline & & Sliced bread & 1 \\
\hline & Sodium $(\mathrm{n}=09)$ & Packaged savoury snack & 7 \\
\hline & & Nuggets & 2 \\
\hline & Total fat $(n=07)$ & Nuggets & 3 \\
\hline & & Sliced bread & 2 \\
\hline \multirow[t]{5}{*}{ Low in/Less/Light } & & Processed cream cheese & 2 \\
\hline & Calories $(n=04)$ & Milk-based beverage with added sugar & 2 \\
\hline & & Cocoa powder & 2 \\
\hline & Saturated fat $(n=04)$ & Packaged savoury snack & 3 \\
\hline & & Cookies & 1 \\
\hline
\end{tabular}

The most commented claims were those on the amount of fat, such as ' $0 \%$ trans fat' and ' $25 \%$ less saturated fat'. According to the participants, they meant that the food did not contain fat, had less fat, or had little fat. Some suspected of the ' $0 \%$ trans fat' claim, stating that this claim appears on the labels even when foods contain fat. 'It has $25 \%$ less saturated fat and sodium. So it means that it is healthier' (male fifth-grader) 'The bun contains fat, but here they claim it does not...' (male, fifth-grader) '... when they write zero trans fat it is not true...!' (female fourth-grader)

The children frequently made comments associating the presence of nutrient claims with positive characteristics of the food, using expressions such as 'healthy', 'health', and 'it's good for us'. In all groups the participants reported that the written information is important because it emphasizes what is in the food, the food's characteristics.

Vitamin $A$ and vitamin $D$, which are good for health! (male fifth-grader)

It is good for us... it has 50\% fewer calories. (female fourth-grader)

The 'light' version will have fewer harmful things... so we eat less of these things that are harmful (female fifth-grader)

... a bad product will become less bad than it already is (male fourth-grader) 


\section{I SCUSSION}

The present study found that $88 \%$ of the packaged foods directed at children in a large Brazilian supermarket were ultra-processed. Moreover, almost half of the UPF directed at children had one or more nutrient claims emphasizing positive nutritional characteristics on the front-of-pack label, mainly regarding the presence/increase of vitamins and minerals, and reduction of trans fats.

Even if certain changes made in foods and highlighted in the form of nutrient claims can be considered beneficial, such as the reduction of saturated fats, sugar, or sodium ${ }^{14}$, the present analysis found that saturated fat and sodium were little emphasized in the studied packages. Most nutrient claims regarding presence/increase of component(s) referred to the addition of vitamins and minerals to products such as sandwich cookies, yogurt, instant fruit drink mixes, and jello. Meanwhile, most claims of reduction/absence regard trans fats in filled cakes, instant fruit drink mixes, and sweetened yogurt.

The results indicate a situation similar to those described by foreign studies, that is, packaged foods directed at children have nutrient claims highlighting positive characteristics of the food on their labels 5 .

The ulra-processed foods directed at children whose packages contained a higher number of nutrient claims are characterized by the amount of added sugar in their formulation (cookies, filled cakes, sweetened yogurt, and candies). The World Health Organization (WHO) recently reported that a significant part of the sugars consumed by the population is hidden in UPF and recommended that added sugar should not exceed $5 \%$ of the total daily caloric intake ${ }^{28}$.

Regarding the frequency of claims mentioning the amount of trans fats, the Brazilian legislation in force at the time of data collection (2013) allowed companies to claim 0\% trans fats even when the food contained as much as $0.2 \mathrm{~g}$ of trans fats per serving. Lack of knowledge and poor interpretation of the 'zero trans fats' claim on food packages may lead to incorrect conclusions because in addition to having access to information, consumers should also be capable of interpreting them ${ }^{29}$.

Resolução RDC n 54/2012, which regulates the use of nutrient claims, does not consider the nutritional composition of the food as a whole, it only affirms that the claim placed on the label cannot be presented in a way that will induce the consumer to make an incorrect interpretation, or suggest that the food is nutritionally complete ${ }^{7}$. Therefore, highlighting the vitamin or mineral content on the front-of-pack label of products with high fat and sugar contents as evidenced by the present study is questionable, to say the least. This situation also goes against the recommendation of the Guidelines for the Brazilian Population, which considers nutrition labeling a tool to help consumers choose and buy healthy foods ${ }^{3}$.

The results indicate the need of revising the regulation with respect to the way in which the industry presents nutrient claims on their products. The North American regulation, for example, states that manufacturers that use a positive nutrition claim on a food label must also highlight the presence of excess saturated and trans fats, sugar, and/or sodium in products where they occur. Additionally, negative claims must use the same font size as positive claims and be placed right beneath them. These warnings are called disclosure statements ${ }^{30}$.

Australia is discussing the possibility of introducing legislation where the nutrient profile of foods is assessed before products are allowed to present nutritional claims on packaged food labels ${ }^{31}$.

In the beginning of 2016, the Pan American Health Organization (PAHO) published the document Pan American Health Organization Nutrient Profile Model, which proposes the use of the tool 'nutrient profile' to classify foods and beverages with excess added sugar, salt, total fats, 
saturated fats, and trans fats. The document recommends placing the nutrient profile when designing and implementing regulatory strategies related to the prevention and control of overweight and obesity, such as nutrition labeling on the front-of-package label of packaged foods ${ }^{32}$.

For the aforementioned recommendation to be eventually implemented in Brazil, it would be necessary to establish maximum allowed amounts of fats and sugars in packaged foods -included in the initial text of RDC $n^{\circ} 24 / 2010$ but suspended by court order ${ }^{18}$. An additional challenge is that manufacturers are not required to disclosure the amount of added sugar in the nutrition facts table?.

On the other hand, changes that could be more often employed by the industry, such as the reduction of saturated fats or sodium, were rarely identified by the present study, possibly because these changes are normally restricted to a few foods, such as packaged chips and nuggets. In spite of the highlighted claim indicates a reduction, these foods could still contain high amounts of fats and sodium, only lower than the previous version. In this type of situation, nutrient claims end up working as a marketing strategy that may induce consumers to assess the quality of the food incorrectly.

Regarding children's perception of the information printed on the labels of UPF, the participants of the focus groups demonstrated familiarity with the use of images on the labels as a marketing strategy. Nonetheless, when the children were asked about the presence and meaning of the information presented as nutritional claims, their comments were more indirect as they questioned, for example, the information regarding the products' fat content. Although the children considered the nutritional claims to be directed at their parents and not at them, comments relating the claims to health aspects were frequent, indicating a possible halo effect. Because of their role as consumers who influence the family's purchases and as future consumers, it is important to develop actions directed at this target population that enable them to read and correctly interpret the information presented on nutrition labels.

\section{CONCLUSION}

Almost half of the ultra-processed foods directed at children sold by a large Brazilian supermarket presented nutrient claims on the front-of-pack label, mostly regarding the content of vitamins and minerals. Focus groups with children indicated that they were somewhat confused about the claims' meaning and focus, but the claims had a noticeable influence on the positive assessment of the product as a whole. The results indicate the need of thoroughly reviewing the highlight of nutrient claims of added vitamins and minerals on the packages of ultra-processed foods.

\section{CONTRIBUTORS}

ND Zucchi was responsible for designing the project, collecting, interpreting, and analyzing the data, and writing the manuscript. GMR FIATES advised all stages of the study, and helped to write and revise the manuscript.

\section{REFERE NCES}

1. Floros JD, Newsome R, Fisher W, Barbosa-Cánovas GV, Chen H, Dunne CP et al. Feeding the world today and tomorrow: The importance of food science and technology. Compr Rev Food Sci Food Saf. 2010; 9(5):572-99. http://dx.doi.org/10.1111/j. 1541-4337.2010.00127.x

2. Brasil. Ministério da Saúde. Conselho Nacional de Saúde. Resolução CNS n ${ }^{\circ}$ 408, de 11 de dezembro de 2008. Aprova as diretrizes para a promoção da alimentação saudável com impacto na reversão da epidemia de obesidade e prevenção das doenças crônicas não transmissíveis. Diário Oficial da União. 2009 [acesso 2015 nov 13]; 9 mar, nº 45. Disponível em: http://conselho.saude.gov.br/ultimas_noticias/ 2010/img/211_ro/Reso408.pdf

3. Brasil. Ministério da Saúde. Departamento de Atenção Básica. Guia alimentar para a população 


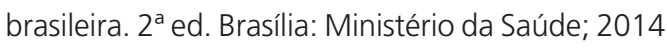
[acesso 2015 out 08]. Disponível em: http://portal saude.saude.gov.br/images/pdf/2014/novembro/ 05/Guia-Alimentar-para-a-pop-brasiliera-MioloPDF-Internet.pdf

4. Harris JL, Pomeranz JL, Lobstein T, Brownell KD. A crisis in marketplace: How food marketing contributes to childhood obesity and what can be done. Annu Rev Public Health. 2009; 30:211-25. http://dx.doi.org/10.1146/annurev.publhealth. 031308.100304

5. Colby SE, Johnson L, Scheett A, Hoverson B. Nutrition marketing on food labels. J Nutr Educ Behav. 2010; 42(2):92-98. http://dx.doi.org/10.10 16/j.jneb.2008.11.002

6. Chandon P. How package design and packagedbased marketing claims lead to overeating. Appl Econ Perspect Pol. 2013; 35:7-31. http://dx.doi.org/ 10.2139/ssrn.2083618

7. Brasil. Agência Nacional de Vigilância Sanitária. Resolução RDC n 54, de 12 de novembro de 2012. Dispõe sobre o Regulamento Técnico sobre Informação Nutricional Complementar, 2012. Diário Oficial da União. 2012; 12 nov [acesso 2015 fev 04]. Disponível em: http://bvsms.saude.gov.br/ bvs/saudelegis/anvisa/2012/rdc0054_12_11_ 2012.html

8. Lobstein T, Macmullan J, Mcgrath T, Witt, J. Cereal offences: A wake-up call on the marketing of unhealthy food to children. Junk Food Generation. London: Consumers International; 2008 [cited 2015 jul 23]. Available from: <http://www.consumer sinternational.org/media/540304/cereal_ offences.pdf

9. Lapierre MA, Vaala SE, Linebarger DL. Influence of licensed spokescharacters and health cues on children's ratings of cereal taste. Arch Pediatr Adolesc Med. 2011; 165(3):229-34. http://dx.doi. org/10.1001/archpediatrics.2010.300

10. Soldavini J, Crawford P, Ritchie LD. Nutrition claims influence health perceptions and taste preferences in fourth- and fifth-grade children. J Nutr Educ Behav. 2012; 44(6):624-27. http://dx.doi.org/ 10.1016/j.jneb.2012.04.009

11. Elliott C, Brierley M. Healthy choice? Exploring how children evaluate the healthfulness of packaged foods. Can J Public Health. 2012; 103(6):453-58.

12. Letona P, Chacón V, Roberto C, Joaquin Barnoya J. A qualitative study of children's snack food packaging perceptions and preferences. BMC Public Health. 2014; 14:1274-79. http://dx.doi.org/ 10.1186/1471-2458-14-1274

13. Chandon P, Wansink B. The biasing health halos of fast-food restaurant health claims: Lower calorie estimates and higher side-dish consumption intentions. J Consum Res 2007; 34(3):301-14. http://dx.doi.org/10.1086/519499

14. Monteiro CA. Nutrition and health: The issue is not food, nor nutrients, so much as processing. Public Health Nutr. 2009; 12(5):729-31. http://dx.doi.org/ 10.1017/S1368980009005291

15. Instituto Brasileiro de Geografia e Estatística. Pesquisa de Orçamentos Familiares no Brasil, 2008-2009. Aquisição Alimentar domiciliar per capita. Rio de Janeiro: IBGE; 2010 [acesso 2015 jul 23]. Dispo-nível em: http://www.ibge.gov.br/home/ estatistica/populacao/condicaodevida/pof/2008_ 2009_aquisicao/

16. Pettigrew S, Pescud M. The salience of food labeling among low-income families with overweight children. J Nutr Educ Behav. 2013; 45(4):332-9. http://dx.doi.org/10.1016/j.jneb.2013.01.025

17. Brasil. Agência Nacional de Vigilância Sanitária. Consulta pública $n^{\circ} 71$, de 10 de novembro de 2006. Diário Oficial da União. 2006; 13 nov [acesso 2015 ago 06]. Disponível em: http://www. anvisa. gov.br/propaganda/minuta_consulta71_2006.pdf

18. Brasil. Ministério da Saúde. Agência Nacional de Vigilância Sanitária. Resolução RDC n²4, de 29 de junho de 2010. Dispõe sobre a oferta, propaganda, publicidade, informação e outras práticas correlatas cujo objetivo seja a divulgação e a promoção comercial de alimentos considerados com quantidades elevadas de açúcar, de gordura saturada, de gordura trans, de sódio, e de bebidas com baixo teor nutricional. Brasília: Ministério da Saúde; 2010 [acesso 2015 jul 23]. Disponível em: http://bvsms.saude.gov.br/bvs/saudelegis/anvisa/ 2011/res0024_14_06_2011.html

19. Brasil. Conselho da Justiça Federal. Anvisa não tem competência para regulamentar propaganda e publicidade comercial. 2013; 25 fev [acesso 2015 jul 23]. Disponível em: http://www.cjf.jus.br/outrasnoticias/2013/fevereiro/anvisa-nao-temcompetencia-para-regulamentar-propaganda-epublicidade-comercial

20. Brasil. Secretaria de Direitos Humanos. Conselho Nacional dos Direitos da Criança e do Adolescente. Resolução n 163, de 13 de março de 2014. Dispõe sobre a abusividade do direcionamento de publicidade e de comunicação mercadológica à criança e ao adolescente. Diário Oficial da União. 2014; p.4, seção1 [acesso 2015 jul 23]. Disponível em: http://www.jusbrasil.com.br/diarios/68613125/ dou-secao-1-04-04-2014-pg-4

21. Brasil. Ministério da Saúde. Agência Nacional de Vigilância Sanitária. Portaria n 949 de 04 de junho de 2014. Institui grupo de trabalho na ANVISA para auxiliar na elaboração de propostas regulatórias 
relacionadas à rotulagem nutricional. Diário Oficial da União. 2014 [acesso 2015 ago 06]. Disponível em: http://bvsms.saude.gov.br/bvs/saudelegis/ anvisa/2014/prt0949_04_06_2014.html

22. Rodrigues VM, Rayner M, Fernandes AC, Oliveira $R C$, Proença RPC, Fiates GMR. Comparison of the nutritional content of products, with and without nutrient claims, targeted at children in Brazil. Brit J Nutr. 2015; 115(11):2047-56. http://dx.doi.org/ $10.1017 / 50007114516001021$

23. Malik VS, Willett WC, Hu FB. Global obesity: Trends, risk factors and policy implications. Nat Rev Endocrinol 2013; 9:13-27. http://dx.doi.org/10.10 38/nrendo.2012.199

24. Krueger RA, Casey MA. Focus groups: A practical guide for applied research. $4^{\text {th }}$ ed Thousand Oaks: Sage Publications; 2009.

25. Nascimento $A B$, Fiates GMR. A qualitative study of brazilian children's habits. Nutr Food Sci. 2013; 43(6):527- 34. http://dx.doi.org/10.1108/NFS-082011-0083

26. John DR. Stages of consumer socialization: The development of consumer knowledge, skills, and values from childhood to adolescence. In: Haugtvedt C, Herr P, Kardes F. Handbook of consumer psychology. New York: Lawrence Erlbaum Associate; 2008. pp. 221-46.

27. Bardin, L. Análise de conteúdo. Lisboa: Edições 70; 2010.
28. World Health Organization. Guideline: Sugars intake for adult and children. Geneva: WHO; 2015 [cited 2015 dez 12]. Available from: http://apps. who.int/iris/bitstream/10665/149782/1/97892 41549028_eng.pdf?ua=1

29. Howlett E, Burton S, Kozup J. How modification of the nutrition facts panel influences consumers at risk for heart disease: The case of trans fat. J Public Policy Mark. 2008; 27(1):83-97. http://dx.doi.org/ 10.1509/jppm.27.1.83

30. Code of Federal Regulations. Food and drug administration. Nutrient content claims: General principles. Silver Spring: FDA; 2012 [cited 2015 dez 12]. Available from: http://www.accessdata. fda.gov/scripts/cdrh/cfdocs/cfcfr/CFRSearch.cfm? $\mathrm{fr}=101.13 \&$ SearchTerm $=$ nutrient

31. Australian New Zealand Food Standards Code. Standard 1.2.7: Nutrition, health and related claims. Australian Government; 2013 [cited 2015 ago 6]. Available from: http://www.comlaw.gov.au/Details/ F2013L00054

32. Pan American Health Organization. Nutrient Prole Model. Washington, DC: PAHO, 2016 [cited 2016 mar 05]. Available from: http://iris.paho.org/xmlui/ bitstream/handle/123456789/18621/97892751 18733_eng.pdf?sequence $=8$

Received: March 15, 2016 Final version: July 7, 2016 Approved: September 6, 2016 